\title{
Research Article \\ Understanding the Changes in the Tourists Perceived Risk after Covid-19
}

\author{
Ana GARCEZ, Ricardo Fontes CORREIA and Adriano COSTA \\ Instituto Politécnico de Bragança, Portugal, CiTUR Guarda - Centro de Investigação, \\ Desenvolvimento e Inovação em Turismo
}

Correspondence should be addressed to: Ricardo Fontes CORREIA; ricardocorreia@ipb.pt

Received date:8 March 2021; Accepted date:3 July 2021; Published date: 21 October 2021

Academic Editor: Bruno Miguel Barbosa de Sousa

Copyright (C) 2021. Ana GARCEZ, Ricardo Fontes CORREIA and Adriano COSTA. Distributed under Creative Commons Attribution 4.0 International CC-BY 4.0

\begin{abstract}
Tourism industry is witnessing a time of uncertainty due to the Covid-19 pandemic. Amidst all the doubts that the industry is experiencing, one certainty is clear: nothing will remain the same after the pandemic outbreak. Tourists have developed new needs that the industry of tourism should be able to understand and fulfill. This study seeks to understand the transformations in tourist consumer behavior caused by the covid-19 pandemic. Thus, based on several assumptions, an explanatory model was developed addressing both the demand side (new consumer preferences) and the supply side (measures and strategies to combat the impacts generated by the perceived risk acquired during the confinement period). The model developed reflects a permanent impact of the Covid-19 crisis on the tourist consumer behavior in terms of accelerating the shift to online services, with a greater emphasis on safety, hygiene and health, as well as environmental and sustainability awareness.
\end{abstract}

Keywords: Tourism; COVID-19; Changes; Motivations; Tourists; Perceived Risk.

\section{Introduction}

In the last decades, the tourism sector has been expanding in almost all countries, exhibiting its potential in terms of the growth and development of societies. Tourism has become one of the most dynamic economic sectors, being considered as an engine for creating job opportunities (direct, indirect and induced) and for local economic development (Cunha, 2013).

In 2019, the sector was responsible for employing 330 million people worldwide, that is, equivalent to $10.3 \%$ of the total global employment with a ratio of one in 10 jobs worldwide. The tourism and travel sector is made up mostly of small and medium-sized enterprises (SMEs), and 144 million jobs are provided by the catering

Cite this Article as: Ana GARCEZ, Ricardo Fontes CORREIA and Adriano COSTA (2021)," Understanding the Changes in the Tourists Perceived Risk after Covid-19", Journal of Eastern Europe Research in Business and Economics Vol. 2021 (2021), Article ID 426881, DOI: 10.5171/2021.426881 
and accommodation industry (WTTC, 2020).

The corona virus pandemic (COVID-19), being a highly contagious and unknown disease, has had an impact on the tourism industry, since the best way to mitigate its spread is through social isolation. In this sense, and due to the fact that this industry is highly fragmented and diversified, covering several sectors, devastating impacts on the world economy and jobs have emerged (OECD, 2020).

This will not only have impacts on the world economy (that are already visible and strong), but will also cause long-term changes in consumer behavior, in relation to the form and frequency of travelers, which, in turn, will require a redefinition of the tourism offer (Sigala, 2020).

In this perspective, the main objective of the present investigation is to understand these changes in the consumer behavior, analyzing them as new motivations and travel needs, while examining the solutions that the supply side can develop in order to respond to such new demands.

The article is structured as follows: Section 2 represents a review of the literature that presents the current context of the effect of Pandemic Covid-19 on international tourism, as well as exploring several factors of risk perception by the consumer.. The following section presents the methodology followed. In section 4 , the model outlined in order to understand the effects of the risk perceived by the consumer in changing his demand pattern is presented. Finally, section 5 summarizes the main features of the article, ending this with limitations and suggestions for future research.

\section{Literature Review}

Tourism depends on thousands of people worldwide who aim to satisfy their needs as visitors to a certain destination. The motivations for traveling are diverse and are directly related to the benefits that tourists can find in the destinations they seek. However, factors such as climate, individual environment, personality, age, economic income and the risk associated with traveling have a great influence on the decision to travel and the choice of the destination (Nascimento \& Santos, 2016; Huber, Milne \& Hyde, 2018). Accordingly, Mira (2018) mentions that tourism is a system that links between visitors, governments, communities, companies, cultures and territories.

\section{International Tourism}

Currently, the tourism sector is arguably one of the largest industries in the world. From the analysis of the official data of the UN World Tourism Organization (UNWTO, 2019), it is possible to see that international arrivals have been increasing in the last ten years, as can be seen from figure 1. 


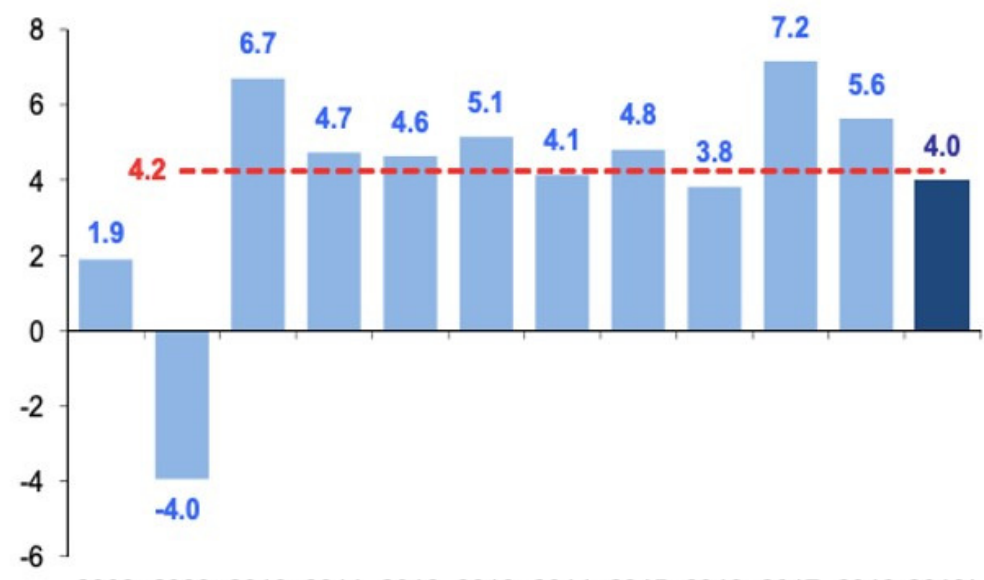

20082009201020112012201320142015201620172018 2019*

$-\infty-\infty$-year average

Figure 1: International Tourist Arrivals (\%)

From figure 1, it is quite clear that 2017 was the year that stood out the most in terms of the number of international arrivals (7.2\%), representing around 1.3 million travelers. In turn, in 2018, international tourist arrivals grew by around $6 \%$ over the previous year, generating approximately 1.7 trillion dollars in global export revenues. The number of international tourist arrivals in 2019 increased by $4 \%$, according to the latest data from the WTO's World Tourism Barometer, which represented 1.5 billion arrivals. In 2019, the tourism sector represented around $28.3 \%$ of the world services exports and $6.8 \%$ of the total exports. The travel and tourism sector exceeded the growth of the global economy by $2.5 \%$, which ended up representing $10.3 \%$ of the global Gross Domestic Product (GDP) (WTTC, 2020).

Until 2020, tourism growth continued to outpace the global economic growth, which demonstrates not only its enormous potential to generate development opportunities worldwide, but also its sustainability challenges. International tourism remains the third largest industry in international trade, following fuels and chemicals (UNWTO, 2020).

The Impact of COVID-19 on International Tourism

On December 1, 2019, a new case of corona virus pneumonia (SARS-CoV-2) was detected in Wuhan, Hubei province in China, which later caused an international public health emergency. This virus, later called COVID-19, was classified as a state of health emergency on January $30^{\text {th }}, 2020$, and then as a pandemic on March $11^{\text {th by }}$ the World Health Organization (WHO). Being an extremely contagious virus, its expansion has been unstoppable, reaching virtually all countries in the world, affecting millions of people and causing hundreds of thousands of deaths (Huang et al., 2020; Li, Zhang, Liu, Kozak \& Wen, 2020). Due to the fact that it was an unknown disease and, therefore, there were no available medicines or vaccines to prevent the virus, health authorities have focused their efforts on implementing quarantines and social detachment. Strategies such as banning travel, mobility and agglomerations, developing awareness campaigns, as well as implementing 
mandatory and voluntary quarantine prevented the development and growth of the tourism sector.

In this sense, and since tourism is an industry particularly vulnerable to environmental, political and socioeconomic crises and disasters, COVID-19 has generated an unprecedented multidimensional impact and long-term structural changes on a global scale (Sigala, 2020; Novelli, Gussing Burgess, Jones \&
Ritchie, 2018). Limited by containment measures, health and hygiene regulations and border closures, the global travel, tourism and hospitality industry are among the sectors most affected by the pandemic, and its repercussions are already very visible (Pappas \& Glyptou, 2021). As can be seen in figure 2 , according to UNWTO data (2020), the first quarter of 2020 witnessed a 22\% decrease in international arrivals globally (57\% in March), representing a loss of approximately 67 million arrivals.

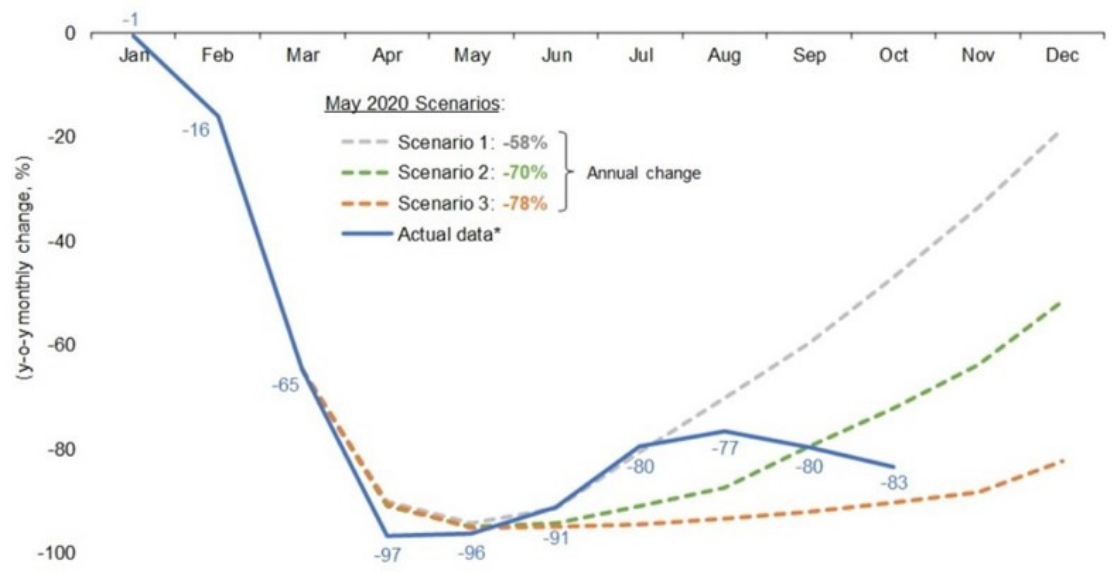

Source UNWTO (2020)

Figure 2: International Tourist Arrivals in 2020

In the month of June, with the slow opening of business and markets, the tourism sector witnessed a recovery; however, from the beginning of September, it started to decline significantly. Thus, according to the data provided by the WTO (2020), a 72\% decrease in international arrivals was confirmed in the first ten months of 2020 , resulting in a loss of 900 million international tourists. All of this generated a loss of 1.1 trillion dollars in international revenues. In this sense, the economic losses caused by the pandemic could reach 2 trillion dollars in the global GDP by the end of 2020.

According to the UNWTO (2020), international arrivals are forecasted to recover in 2021, due to a large-scale distribution of the vaccines. In this way, traveler's confidence will be regained when travel restrictions are lifted gradually. That being said, the recovery is expected to continue in 2022; however, it may take international tourism two to four years to return to 2019 levels.

However, the impacts generated by COVID19 will be unequal in time and space, because as people experienced a slower pace of life, their priorities and social values were redefined as new lifestyles and work patterns emerged (Sigala, 2020). In view of all this, profound changes in the behavior of the tourist consumer will be triggered, and new needs and desires will 
emerge. In this sense, it is up to tourist destinations, companies and organizations to understand the psychological state of their customers in post-pandemic travel and not just predict their demands, in order to create conditions capable of responding to the new needs (Zhenga, Luo \& Ritchie, 2021).

\section{Perceived Risk}

Tourism is a particularly vulnerable industry, since its activity is largely dependent on external and uncontrollable factors, such as economic and financial crises, natural disasters, political instability and infectious diseases (Cró \& Martins, 2017; Ritichie \& Jiang, 2019; Okuyama, 2018). In this sense, the impact of COVID19 on the tourism sector is not only reflected in the reduction of revenues in the supply side, but also in the perceptions of risk in the demand side (Li, Zhang, Liu, Kozak \& Wen, 2020). Safety has always been a key factor in the decision to travel; however, the perceptions of risk vary according to the characteristics inherent to each individual. In this context, and according to Featherman and Pavlou (2003), the perceived risk refers to the sensation of consumer uncertainty and the potential negative consequences related to products or services. Thus, in the circumstances currently experienced and caused by the pandemic, the perceived risk can affect the choice of a destination and the travel behavior of tourists.

In the current pandemic scenario, there are several risk perception factors that significantly impact demand and, consequently, tourism supply. Right from the start, the health risk, according to Han (2005), refers to the fear of the possibility of getting ill. COVID-19 is a highly infectious disease and due to social distance, it was perceived as a high risk for health to travel to unknown destinations and interact with strangers (Liu et al., 2017).

Another dimension of risk is the psychological risk that relates to the anxiety created by the pandemic (missing a flight, being stranded in a hotel, being infected, etc.) (Simpson \& Siguaw, 2008).

The social risk can also be considered as part of the perceived risk, and it refers to the way in which others will react to a particular tourism related purchase, since, in the current context and due to the restrictions imposed during the pandemic (quarantine, curfew), the decision to travel can be interpreted negatively by friends, family and associates, leading to a potential loss of esteem, respect or friendship (Sönmez \& Graefe, 1998).

Social distance and the corresponding restrictions imposed by the government can change the performance of a certain product or service, thus generating fear on the part of the consumer to purchase any product or service, since its "performance" may not be as expected (Khan et al., 2017), namely, generating a performance risk.

Finally, the last dimension of the perceived risk is the image risk that can be understood as the general impression that people have about a particular country or destination, generating negative publicity of it. China, in the case of COVID-19, could be a good example, since in the beginning of the pandemic, the virus was inadequately labeled by some media as a disease originating in China, generating feelings of fear and discrimination and ultimately affecting the choice of tourists (Weng et al., 2020).

\section{Methodology}

The purpose of this study is purely conceptual. It is intended to clarify the influence of risk perception by the tourist consumer caused by the Covid-19 pandemic on their behavior and simultaneously on the tourist offer that is expected to evolve in order to respond to the changing needs in demand. Given its exclusively conceptual and exploratory nature, it was considered appropriate to follow a qualitative methodology to guide the study through developing a theoretical 
model based on the literature review carried out in the previous chapter. The model was developed with two main concerns: reflecting the new motivations and needs of the consumer, while exposing the possible restructuring of the offer to meet the new existing demand. In summary, the proposed explanatory model portrays the way in which the perception of the perceived risk (considering the health, psychological, social, performance and image dimensions) changes consumer behavior and needs, thus requiring the reformulation of the tourist offer, generating values and benefits, in order to assist the traveler's needs.

\section{Theoretical Model and Discussion}

\section{Perceived Risk}

The model represented in figure 3 shows the five attributes of risk perception derived from COVID-19 that significantly impact the demand by the tourist consumer, considering, as previously mentioned, health, psychological, social, performance and image dimensions. In view of the new perception of risk, new habits, needs, demands and behaviors emerged. In accordance with some authors and studies developed by tourist entities (Chebli \& Foued, 2020; Sigala, 2020; Borges, 2020; IPDT, 2020; amadeus, 2020; UNWTO, 2020), the main trends in the tourism sector were determined both on the demand and supply side, as can be seen from the model presented (figure 3).

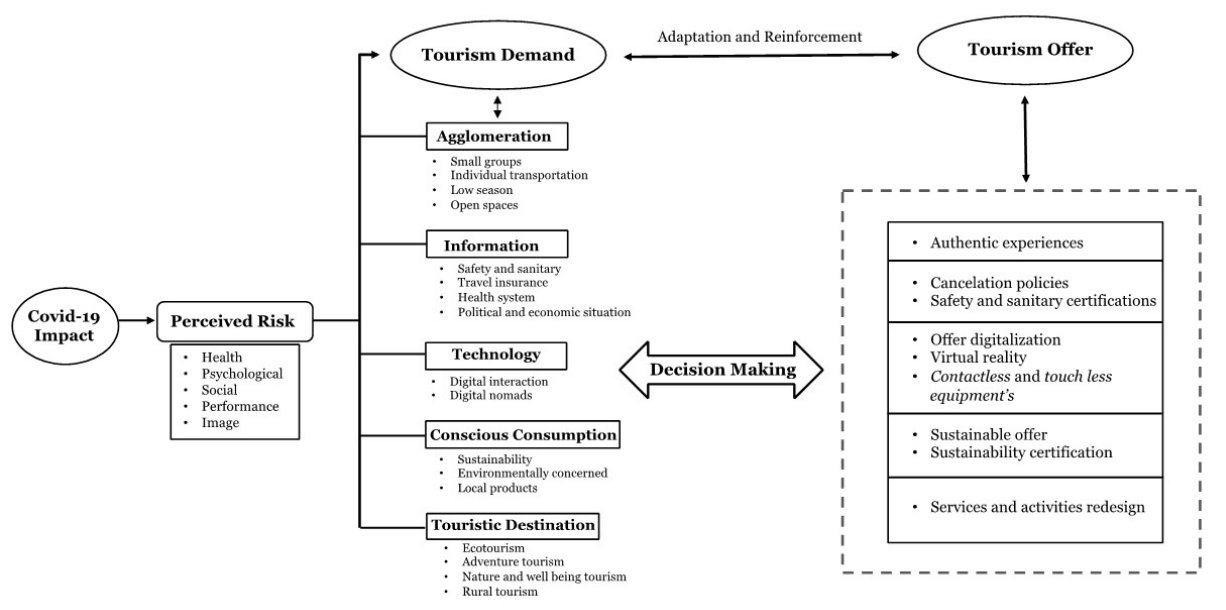

Figure 3: Research Model about the Covid-19 Impact on the Perceived Risk

\section{Tourism Demand}

The time experienced during the quarantine and the prophylactic isolation significantly changed people's perspective regarding the agglomerations. Crowded places, mass destinations, group travel, public transport, closed spaces and high season holidays now represent a "threat". In this sense, the demand for less popular destinations, bike rides, and trips outside rush hour, and the demand for taxis and private transport applications as well as for direct air connections are expected to increase. The pandemic also highlighted the need for unity among people. For this reason, in the long run, tourists will seek enriching experiences in family or in relatively small groups, with unique and educational activities.

Increasingly, tourists express a desire to learn and acquire information about the 
destination they intend to travel to. Thus, COVID-19 reinforced this aspect even more, as the price will no longer be a determining element for traveling somewhere. Now tourists will be more attentive to the cleanliness and sanitary hygiene of the establishments and will prioritize safety, opting for slightly more expensive destinations and offers if they can enjoy safer experiences. The same will happen with travel insurance and flexible rates as tourists will no longer be willing to take risks. It is important to mention that the search for information regarding the political and economic situation and the health system of the destination to which they intend to travel is also seen as a trend.

The internet, technologies and artificial intelligence will be a focal point for decision making. The demand for establishments that offer computers, printers and meeting rooms will increase, as more and more travelers are adopting the attitude of "working anywhere" calling themselves "digital nomads". On the other hand, online shopping (e-commerce) will tend to increase even more, reaching a larger number of market segments.

Future tourists are more concerned with environmental preservation and in case this is not offered, they will look for alternative destinations.. The pandemic generated more conscious consumption in relation to what you buy and to whom you buy. Exaggerations, waste and unnecessary purchases will not be well regarded by responsible consumers, thus choosing to travel in a more ecological and minimalist way. Tourists are expected to select destinations that promote sustainability practices, as well as local products, in order to support small and medium-sized companies.

Given all this, it is expected that nature and well-being tourism will be in the top-ofmind of tourists, as well as adventure tourism, ecotourism and rural tourism. In other words, outdoor activities and nonmassified places will be the preferred choice, as these places satisfy the need to visit and experience new cultures, gastronomies and traditions at a slower and safer pace.

\section{Tourism Offer}

All expected changes in demand require a redesign of the supply structure in order to respond to them. In this context, and as can be seen in Figure 4, it is the responsibility of destinations and tourist organizations to develop strategies and resources in order to combat the adversities caused by COVID19. The activities of tourist entities must essentially consider promoting the feeling of security (health, food, social, etc.). In this sense, cleanliness and hygiene will be essential for the decision making of the traveler. Thus, the offer must acquire certificates that guarantee its compliance with hygiene and safety measures in accordance with the best practices for combating and preventing COVID-19. Human resources should also receive specific training regarding risk protection and prevention measures, and the monitoring of compliance with the measures should be followed up more frequently in order to assure security.

Flexibility in canceling reservations may also be a strategy to respond to the new needs, as well as digitizing the offer both on the websites and on other platforms (social networks, blogs, review websites, etc.). This trend should be available at all times during the trip (before, during and after). That being said, aspects such as online check-in in hotel establishments and airports, providing contactless and touchless equipment and creating a QR Code for reading information may be good practices to face the new circumstances, as tourists won't easily accept a non digital service knowing that it is possible to have the same service digitalized. Virtual reality will also be an aspect to take into account, both in the hotel sector and in other tourism domains, since this type of technology allows users to "enter" hotels, museums, galleries, restaurants, etc., and live differentiated experiences without actually going there.

The offer of differentiated and authentic experiences and packages, which value the 
local community, generate real benefits for residents and prioritize the family, sustainability, well-being and nature must be addressed.

In general, the best way to respond to this new segment of tourists is to operate in the appropriate markets, that is, with a greater predisposition to travel. There must be a constant monitoring of the evolution of the pandemic in both the nearby and in the main faraway markets in order to define the best communication and promotion strategy for tourist destinations and services. In addition, it is considered important to keep digital channels active and to define an articulated strategy between the tourism sector and the health sector.

\section{Conclusion}

The world is facing a global social, economic and health emergency arising from the COVID-19 pandemic. The travel and tourism sector suffered an abrupt drop in terms of the international demand, due to restrictions imposed to curb the spread of the virus (UNWTO, 2020). In this sense, the pandemic generated impacts that are reflected not only on the reduction of revenues in the supply side, but also on the emergence of new behaviors, needs and requirements caused by the perceived risk in the demand (Simon, 2009).

Thus, and in accordance with the explanatory model developed, it was possible to conclude that safety and hygiene are key factors influencing the decision to travel. Sustainability, awareness, as well as touchless and contactless technologies are the aspects that define the new tourist demand, as well as nature and wellness tourism, outdoor activities and the search for non-mass destinations. In other words, destinations perceived as safe, including low-density territories, will be at the center of preferences in the coming years of recovery until the pandemic is over.

In this sense, it is important for those responsible for tourism to understand tourists' fears and concerns in order to be able to develop measures and strategies, adapted to the new reality and capable of responding quickly to the needs and desires of new consumers without exposing them to risks.

\section{Limitations and Suggestions for Future Research}

The main limitation of this work lies in its purely conceptual nature. Thus, this investigation should be seen as an exploratory reflection exercise, translated into a model of analysis of a reality that, involving multiple actors, proves to be very complex. The presented model therefore lacks a further empirical validation.

Being a very recent and an unknown topic, there are numerous future research possibilities. However, for a future line of research, it is suggested to analyze and define the profile of the new tourist. It is also recommended to assess whether the socio-demographic characteristics, that influence the risk perception of tourists, is a relevant line for future research. Another study suggestion would be to analyze the impact of COVID-19 on the use of digital media, in the tourist context.

\section{References}

- amadeus, 2020. amadeus. [Online] Available at: https://amadeus.com/pt/insights/blo g/tendencias-para-2021-historia-daretomada-das-viagens [Retrieved on December 2020].

- $\quad$ Borges, M., 2020. Turismo pós Covid-19: Insights para empresas e destinos. [Online]

Available at:

https://agentenoturismo.com.br/2020 /04/19/turismo-pos-covid-19-

insights-para-empresas-edestinos/[Retrieved on December 2020].

- Chebli, A. \& Foued, B., 2020. The Impact of Covid-19 on Tourist Consumption Behaviour : A Perspective Article. Journal of Tourism 
Management Research, 7(2), pp. 169207.

- Cró, S. \& Martins, A., 2017. Structural breaks in international tourism demand: Are they caused by crises or disasters?. Tourism Management, Volume 63, pp. 3-9.

- Cunha, L., 2013. Economia e Política do Turismo. Lisboa: LIDEL.

- Featherman, M. \& Pavlou, P., 2003. Predicting e-services adoption: a perceived risk facets perspective. International Journal Human- Computer Studies, Volume 59, pp. 451-474.

- Han, J., 2005. The Relationships of Perceived Risk to Personal Factors, Knowledge of Destination, and Travel Purchase Decisions in International Leisure Travel, s.l.: Virginia Tech.

- Huang, C. et al., 2020. Clinical features of patients infected with 2019 novel coronavirus in Wuhan, China. The Lancet, 395(10223), pp. 497 - 506.

- Huber, D., Milne, S. \& Hyde, K. F., 2018. Constraints and facilitators for senior tourism. Tourism Management Perspectives, Volume 27, pp. 55-67.

- IPDT, 2020. Guia para a retoma do Turismo. [Online] Available at: https://www.ipdt.pt/ebook-retomaturismo-covid/

[Retrieved on December 2020].

- Khan, M., Chelliah, S. \& Ahmed, S., 2017. Factors influencing destination image and visit intention among young women travellers: role of travel motivation, perceived risks, and travel constraints. Asia Pacific Journal of Tourism Research, 22(11), pp. 11391155.

- Li, Z. et al., 2020. Seeing the invisible hand: Underlying effects of COVID-19 on tourists' behavioral patterns. Journal of Destination Marketing \& Management, Volume 18, pp. 1-12.

- Liu, W., Batra, R. \& Wang, H., 2017. Product touch and consumers' online and offline buying: The role of mental representation. Journal of Retailing, 93(3), pp. 369-381.

- Mira, M. d. R., 2018. Dimensões e fatores de internacionalização de destinos turísticos: Um modelo sistémico., s.l.: Universidade de Aveiro.

- Nascimento, F. \& Santos, A., 2016. Os fatores motivacionais na prática da atividade turística na terceira idade: um estudo a partir de um centro de convivência de idosos na cidade de Manaus. Revista de Turismo Contemporâneo, 4(1), pp. 1-22.

- Novellia, M., Burgess, L., Jones, A. \& Ritchie, B., 2018. No Ebola...still doomed' - The Ebola-induced tourism crisis. Annals of Tourism Research, Volume 70, pp. 76-87.

- OECD, 2020. Tourism Policy Responses to the coronavirus (COVID-19). [Online] Available at: https://www.oecd.org/coronavirus/p olicy-responses/tourism-policyresponses-to-the-coronavirus-covid19-6466aa20/[Retrieved on December 2020].

- Okuyama, T., 2018. Analysis of optimal timing of tourism demand recovery policies from natural disaster using the contingent behavior method. Tourism Management, Volume 64, pp. 37-54.

- Pappas, N. \& Glyptou, K., 2021. Accommodation decision-making during the COVID-19 pandemic: Complexity insights from Greece. International Journal of Hospitality Management, Volume 93, pp. 1-9.

- Ramos, D. M. \& Costa, C. M., 2017. Turismo: tendências de evolução. Revista Eletrônica de Humanidades do Curso de Ciências Sociais da UNIFAP, 10(1), pp. 21-33.

- $\quad$ Ritchie, B. \& Jiang, Y., 2019. A review of research on tourism risk, crisis and disaster management: Launching the annals of tourism research curated collection on tourism risk, crisis and disaster management. Annals of tourism Research, Volume 79, pp. 1-15.

- Sigala, M., 2020. Tourism and COVID19: Impacts and implications for advancing and resetting industry and research. Journal of Business Research , Volume 117, pp. 312-321.

- Simon, H., 2009. The crisis and customer behaviour: Eight quick solutions. Journal of Customer Behaviour, 8(2), pp. 177-186. 
- Simpson, P. \& Siguaw, J., 2008. Perceived travel risks: the traveller perspective and manageability. International Journal of Tourism Research, 10(4), pp. 315-327.

- Sönmez, S. \& Graefe, A., 1998. Determining Future Travel Behavior from Past Travel Experience and Perceptions of Risk and Safety. Journal of Travel Research, 37(2), pp. 171-177.

- UNWTO, 2001. Tourism: 2020 Vision Global Forecast and Profiles of Market Segments. [Online].

- UNWTO, 2019. UNWTO World Tourism Barometer and Statistical Annex, November 2019.

- [Online] Available at: http://www.dadosefatos.turismo.gov.b r/images/demanda/UNWTO World T urism Barometer 2019 Edition.pdf $[\operatorname{Re}$ trieved on December 2020].

- UNWTO, 2020. Impact assessment of the covid-19 outbreak on international tourism.

[Online]

Available at:

https://www.unwto.org/impactassessment-of-the-covid-19-outbreakon-international-tourism[Retrieved on December 2020].
- UNWTO, 2020. International Tourism and COVID-19. [Online]

Available at: https://www.unwto.org/internationaltourism-and-covid-19

[Retrieved on December 2020].

- UNWTO, 2020. Sustainability as the new normal" a vision for the future of tourism.

[Online]

Available at:

- https://www.unwto.org/covid-19oneplanet-responsible-recovery [Retrieved on December 2020].

- Weng, J., Aston, J., Liu, X. \& Ying, T., 2020. Effects of misleading media coverage on public health crisis: a case of the 2019 novel coronavirus outbreak in China. Anatolia, 31(2), pp. 1-6.

- WTTC, 2020. Economic Impact Reports. [Online]

Available at: https://wttc.org/Research/EconomicImpact [Retrieved on December 2020].

- Zhenga, D., Luo, Q. \& Ritchie, B., 2021. Afraid to travel after COVID-19? Selfprotection, coping and resilience against pandemic 'travel fear'. Tourism Management, Volume 83. 